\title{
GOOD MANUFACTURING PRACTICE: THE ROLE OF LOCAL MANUFACTURERS AND COMPETENT AUTHORITIES
}

\author{
Siniša TOMIĆ, Anita FILIPOVIĆ SUČIĆ, and Adrijana ILIĆ MARTINAC \\ Agency for Medicinal Products and Medical Devices, Zagreb, Croatia
}

Received in February 2010

Accepted in November 2010

\begin{abstract}
In every country, a manufacturer of medicinal products for either human or veterinary use is required to operate in compliance with local legislation. In all EU Member States, legislation is approximated to the effect that they are committed to abide by the same standards. The candidate countries transpose the acquis into their national legislation, including the good manufacturing practice (GMP). Consequently, the local manufacturer is required to strictly comply with GMP and the manufacturing licence, including for medicinal products exclusively intended for export. A vital role is also played by national regulatory authorities, in Croatia by the Agency for Medicinal Products and Medical Devices which issues the manufacturing licence, GMP certificate, and the Certificate of a Pharmaceutical Product (CPP) and conducts laboratory control of products. GMP inspection is carried out by the Pharmaceutical Inspectorate with the Ministry of Health and Social Welfare. Both authorities are responsible only for human medicines. There are legislative issues not yet harmonised with the acquis, but as a country aspiring for the EU membership, Croatia is expected to demonstrate that its industry and competent authorities are able to conform to current requirements and thus fully adhere to the integrated European regulatory network. Hence the importance of strengthening the institutional capacity of the competent authorities, as insufficient resources may have a direct bearing on patients by limiting their access to affordable treatment.
\end{abstract}

KEY WORDS: inspection, medicinal product, production, quality assurance, quality control, qualified person

Today we are facing difficulties in securing a safe production and distribution chain for medicinal products. This is exemplified by recent occurrences of contaminated heparin (1) causing severe anaphylactoid reactions, or the global recall of nelfinavir $\left(\right.$ Viracept $\left.^{\mathbb{R}}\right)$ due to contamination with ethyl methanesulfonate (2). Furthermore, the ever increasing presence of counterfeit medicines, also in the EU, poses a serious risk to public health $(3,4)$. Pharmaceutical manufacturers are obligated to apply GMP standards with strong emphasis on quality assurance and quality control (QA/QC) within the production process. Since the output is a human medicine, $\mathrm{QA} / \mathrm{QC}$ procedures monitor and test the production process carefully to ensure that no patients will be harmed (5). The Croatian manufacturers and competent authorities are implementing the acquis which has been adopted into national legislation. In this pre-accession period there are still discrepancies in terms of the roles of manufacturers and the Agency responsible for medicines locally produced and those produced in other countries, including the EU (6). This article analyses the role of competent authorities, particularly of the Agency for Medicinal Products and Medical Devices (Agency), in the supervision of drug production and quality assurance, as well as the 
role of the Pharmaceutical Inspectorate. The Agency is assigned the important task of granting GMP certificates for products manufactured in Croatia, granting certificates of pharmaceutical products (CPPs), granting manufacturing licences to local manufacturers and withdrawing them when needed, and conducting quality control of products entering the country and retesting them by taking samples from pharmacy shelves.

\section{GOOD MANUFACTURING PRACTICE}

The concept of good manufacturing practice (GMP) is applied to any activities involving production management and operation. It is indispensable in pharmaceutical production, and its principles must be observed at all stages, from the production of active substances to the finished product. Patients expect to get a safe, efficient and quality medicinal product $(7,8)$. GMP is intended to ensure drug production that would consistently meet all these requirements. Traditionally, drug manufacturers have relied on quality control (QC) procedures, based on the concept of testing the finished product for compliance with specifications, which in itself, however, is no guarantee that the product will possess the desired quality. For that reason, current procedures include quality assurance (QA) with emphasis on quality, from design to the finished product. QA/QC are a part of GMP that provides efficacious drug production and distribution systems within an appropriate environment and by trained and qualified personnel.

\section{Qualified personnel}

A qualified personnel includes production operations and quality control people. In addition, the manufacturer is required to provide a sufficient number of trained quality assurance people. This in the first place refers to people qualified for batch (lot) release, as they issue certificates for placing production batches on the market. Qualified person should be a university graduate educated in subjects specified in the Directive 2001/83/EC (9). In Croatia, these requirements best correspond to the Pharmacy Graduates, who are additionally specialised in drug testing and control for three years, or should have at least five-year experience in relevant jobs to qualify for such a position (6).The EU demands only two years of relevant experience. According to Croatian legislation (10) a qualified person for batch release in cases of the manufacture of specific medicinal products (biologics, radiopharmaceuticals, medical gases) and pharmaceutical forms may also graduated in medicine, veterinary medicine, chemistry, biology and other scientific disciplines, but should possess at last five-year experience in pharmaceutical quality control. The qualified person is a person responsible to release each batch of medicinal products for marketing (11).

\section{Production premises and equipment}

Production premises and equipment should be located, designed and managed in a way which will minimise the risk of error and facilitate efficient cleaning and maintenance with a view to avoiding contamination, cross contamination, and any other undesired effects on product quality. Likewise, premises and equipment used in production are critical for product quality and they should be properly qualified and validated (12).

\section{Documentation}

The manufacturer should establish and maintain a record-keeping system based on product quality requirements, pharmaceutical manufacturing formulations, manufacturing instructions, finished pharmaceutical product packaging instructions, operating procedures, and records covering different production processes in order to demonstrate that operations are carried out in conformance with GMP. Records must be clear, without mistakes, and updated. Batch documentation should be kept for at least one year after the expiry date of the batch concerned or five years after placing a batch on the market, whichever comes later. Different production procedures should be carried out according to pre-established written instructions and procedures and in line with GMP. Any deviations from the established procedures and any damage to the product should be properly documented and thoroughly investigated. To avoid cross contamination or submixing, all necessary technical and organisational measures should be taken. Each new production procedure or major modification of the existing production procedure should be validated. The critical stages of a production procedure must be re-validated at regular intervals (13).

\section{Process analytical technology}

Process analytical technology (PAT) has been defined by the United States Food and Drug Administration (FDA) as a mechanism to design 
and control pharmaceutical manufacturing processes through the measurement of critical quality parameters within given timeframes, aimed to assure the finished product quality. The PAT concept is aimed at understanding production by defining its critical process parameters and by monitoring them (preferably in-line or on-line). This ensures greater testing efficiency, reduces over-processing, enhances consistency, and minimizes rejects. The concept is designed for the manufacturer to identify and measure all quality impact factors, so that the finished product fulfils its pre-defined characteristics from the start of production, which is also referred to as quality by design. Even though PAT activities are not a current requirement of the GMP in the EU, in 2003, the EMA created a forum for dialogue and understanding with the aim of reviewing the implications of PAT and ensuring that the European regulatory framework and authorities are prepared for and adequately equipped to conduct thorough and effective evaluations of PAT-based submissions. The EMA believes that the current regulatory framework in Europe is open to the implementation of PAT in marketing authorisation applications. Moreover, the International Conference on Harmonisation Guideline on Pharmaceutical Development (ICH Q8), which includes provisions on the use of PAT applications, has also been adopted by the EU.

\section{Quality control}

The manufacturer should establish and maintain a quality control system run by a qualified person independent of production. This person should have at his or her disposal one or more quality control laboratories staffed and equipped to test starting and packaging materials, intermediate and finished products. To this end the services of other qualified laboratories may be used, i.e. those meeting GMP requirements, which are authorised in the procedure for granting the manufacturing license, and with which the manufacturer has a valid written contract. The final checking of finished medicinal products, before placing them on the market, should take into account not only analytical results, but all other relevant information such as production conditions, results of process control, production documentation, and whether the product meets the set quality requirements, including its final packaging $(14,15)$.

\section{Complaints and recalls}

The manufacturer should establish a system of labelling and evaluating all complaints related to product defects and an efficient system to recall defective medicinal products. Finished products should be labelled and isolated pending checks for conformity to product specification. QA procedures should ensure that a defective finished product is an exception. The manufacturer must notify local competent authorities and, if possible, the country of destination of any product defect that may result in its recall or in restricted application $(16,17)$.

\section{Self-inspection}

The QA system requires that the manufacturer monitors and oversees compliance with GMP and proposes measures to improve the QA system. Selfinspection is internal and a record is kept for all inspections and corrective measures (18).

\section{COMPETENT AUTHORITIES}

\section{Agency for Medicinal Products and Medical Devices}

Competent authorities for GMP for medicinal products for human use in Croatia are the Agency for Medicinal Products and Medical Devices and the Ministry of Health and Social Welfare's Pharmaceutical Inspection Department. The Agency grants the manufacturing license, certificate of a pharmaceutical product (CPP), and good manufacturing practice certificate (Figure 1) and the Ministry verifies compliance with GMP/GDP (Good Distribution Practice), Good Clinical Practice (GCP), Good Laboratory Practice (GLP), and conducts pharmacovigilance inspection.

\section{Procedure for granting manufacturing licence}

Manufacturing licence is not required for making extemporaneous and galenic formulations at pharmacies or laboratories, but it is for industrial drug production. Agency appoints a technical commission which makes an inspection to verify that the manufacturer meets GMP requirements. The technical commission consists of pharmaceutical inspectors and experts in relevant fields. Pharmaceutical inspectors issue a written opinion based on inspection report and, in the event of deficiencies found at inspection, also based on the applicant's response to the report. In its report, inspection encourages the manufacturer to set in motion its corrective and preventive action (CAPA) system. The aim of the CAPA 


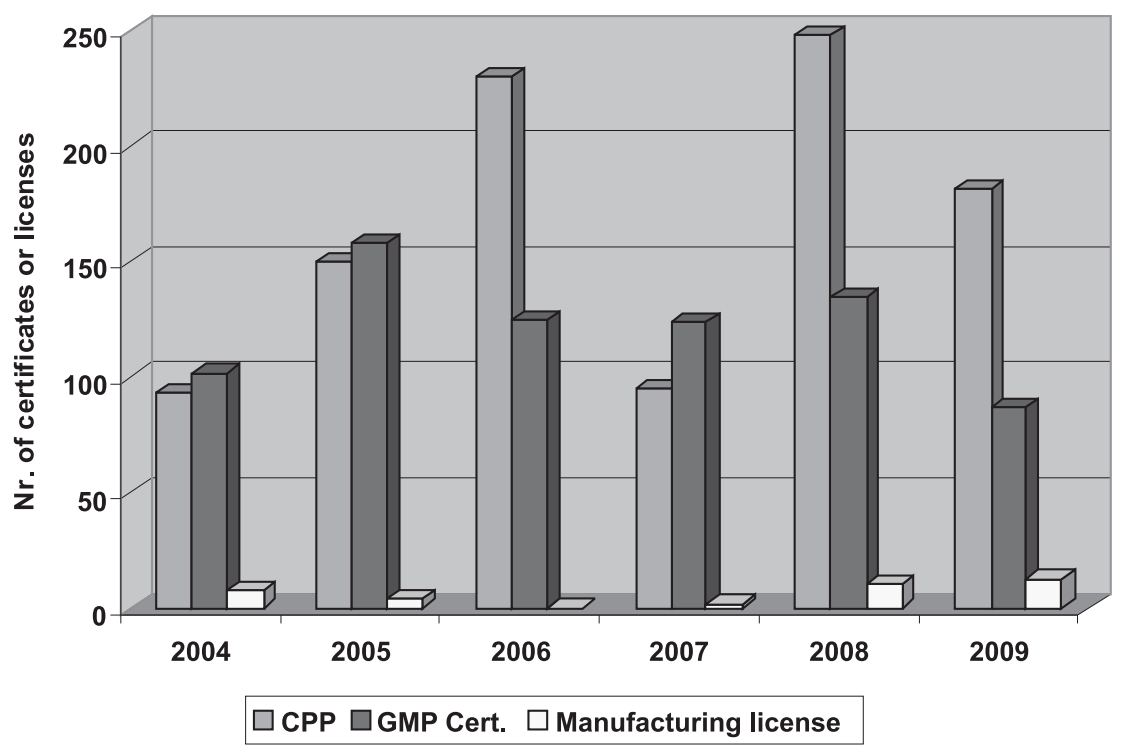

Figure 1 Certificates of a pharmaceutical product (CPP), good manufacturing practice certificates (GMP) and manufacturing licenses granted by the Agency

systems is to ensure that deficiencies/deviations/ non-conformance, product complaints, external and internal audit observations, annual product reviews, recommendations, and regulatory issues are identified, fully investigated to their root cause, and properly assessed by the manufacturer. If the applicant does not meet all the prescribed GMP requirements, the Agency may grant a temporary manufacturing licence for a term shorter than five years $(6,10)$.

\section{GMP certificate}

The holder of the manufacturing licence may apply for a GMP certificate that generally summarises the contents of the manufacturing license in one page. According to Croatian legislation, the issuance of the certificate is subject to meeting GMP requirements laid down in the procedure of issuing the manufacturing licence or to a satisfactory on-site audit by the pharmaceutical inspector. However, Directive 2001/83/ EC (9) stipulates that an inspection is required before any GMP certificate is granted. If inspection verifies GMP compliance, the certificate is granted within 90 days.

The certificate for a medicinal product or pharmaceutical form granted by the Agency specifies the place of production, production facility or facilities, and parts of the production process. GMP certificate does certify manufacturer's capability to maintain the consistency in the quality of an active pharmaceutical ingredient, so it is vital that on-site audits are performed. If an application for a GMP certificate is submitted three years or more since the manufacturing licence was issued or since the latest audit was performed, the Agency will seek an opinion from the pharmaceutical inspectorate as to confirm whether GMP requirements have been met $(10,19)$.

\section{Certificate of a pharmaceutical product}

The certificate of a pharmaceutical product (CPP) is a voluntary certification scheme set up by the World Health Organization (WHO) and is issued by competent national authorities upon request from either the local manufacturer, the customer, or the authorities in the importing country. The certificate is issued for a specific product and indicates whether or not the product is marketed in the country of origin. Furthermore, it states that the manufacturer complies with GMP and that the pharmaceutical product is inspected regularly by the competent national authority.

CPP issued by the Agency provides a partial assurance to countries with limited drug regulatory capacity that a pharmaceutical product which they plan to import is safe, effective, and of good quality.

\section{Sampling and testing programme}

Any medicinal product, either imported or locally manufactured, to be marketed in Croatia must hold the Agency's marketing authorisation. The manufacturer 
must ensure that all production procedures are in compliance with data submitted to the Agency when applying for marketing authorisation of a finished product. Croatia-based manufacturers need to verify the quality of each batch of a finished product that is to be released for marketing in Croatia. For finished medicinal products imported to Croatia, it is the responsibility of the importer to verify that they comply with GMP. At the request of the competent authority, the importer must provide evidence that the product has been manufactured by a manufacturer holding the manufacturing licence. Both the local manufacturer and the importer are required to submit to the Agency samples of every first manufactured or imported batch for quality control. The Agency's approval of every batch imported from the EU is based on a certificate of analysis endorsed by a EU qualified person (QP) (Figure 2). Both the analysis of the first batch and the issuance of approval for imported batches from a single European market will cease to apply when Croatia becomes the EU member state, because they would be in contravention of the free movement of goods. Besides, medicinal products in the EU which are properly controlled and released for marketing by a QP do not have to be retested by any competent authority in the EU. Hence the Agency will steer its quality control towards the so-called riskbased approach of taking samples from the market.
This principle of off-the-shelf drug testing is also practised in this pre-accession period, where every medicinal product is taken off the shelves once in five years for testing by the Agency. In case of any doubt about the quality of a medicinal product or reported adverse effects, such a product may be ad hoc sampled and retested. If it is a third-country product, samples of each imported batch should be submitted to the Agency for testing (6).

\section{The role of the inspector}

GMP inspectors must be highly trained in all relevant areas of QA/QC management, production procedure, drug control, and distribution and inspection methodology (20). Apart from the EMA guidelines on the training and qualifications of GMP inspectors, each country may have additional requirements. In Croatia these are defined by a special ordinance (21). It is desirable that an inspector has qualifications as specified for the qualified person referred to in Directive 2001/83/EC (9) for human medicinal products and in Directive 2001/82/EC (22) for veterinary medicinal products. It is necessary to constantly assess the educational needs of inspectors and take steps to improve their skills. Organisationally, the GMP inspectorates in the Member States, with the exception of Germany, The Netherlands, and Poland, are attached to the national medicines agencies,

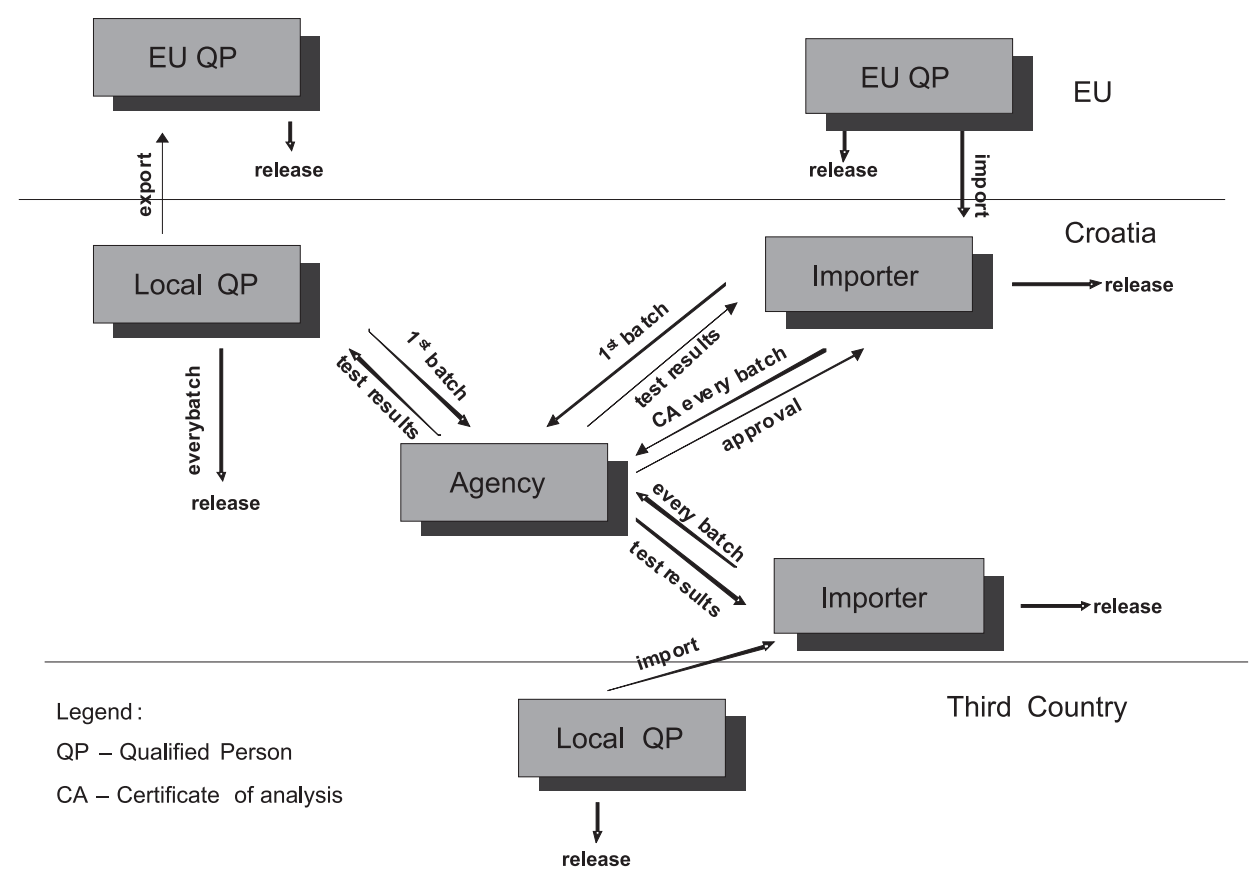

Figure 2 Batch release of locally manufactured and imported batches in Croatia according to local legislation (6) 
which makes them a constituent part of an integrated regulatory system. In Croatia, the Agency is responsible for the issuance of manufacturing licences, GMP and CPP certificates, whereas the GMP audit itself is the responsibility of the Pharmaceutical Inspectorate of the Ministry of Health and Social Welfare. Furthermore, the Inspectorate for Veterinary Medicinal Products is part of the Veterinary Directorate at the Ministry of Agriculture, Forestry and Rural Development. The inspectorate for human medicines performs regular and extraordinary inspections of drug manufacturers. Regular inspections are performed every two to three years. Extraordinary inspections are undertaken in case of incident situations, serious complaints, product recalls, product defects detected by the Agency, doubts about product quality or signs of unusual occurrences and other circumstances, with an aim to ensure product quality. Serious non-compliance by definition requires administrative action to be taken by the inspector.

\section{Quality defects and batch recalls}

Every health care professional, physician, or pharmacist is required to report a defective medicinal product to the Agency, which, depending on the degree of urgency, takes appropriate action that may include recalling the product from the market (23). Batches or marketing authorisation may also be suspended due to pharmacovigilance issues, where an unexpected signal of an adverse drug reaction or unexpected grouping of signals linked to certain batches occurs. Every marketing authorisation holder in Croatia should have in place an efficient product recall procedure and report recall to the Agency and relevant authorities in other countries. The Agency informs the public and health care services about the recall of defective products on its web pages and through the National Information Centre, which is responsible for immediately informing hospitals and other health care institutions. In 2009, only five batches were recalled from the Croatian market, compared with 15 in 2007. In most cases, however, product batches are recalled by the manufacturer himself, who notifies the Agency of suspected defects.

\section{INTERNATIONAL CO-OPERATION}

\section{European Economic Area (EEA)}

The European Medicines Agency (EMA) is responsible for the maintenance and public release of the collection of European inspection procedures and exchange of information. Under Directive 2003/94/EC (24) all Member States are committed to take these procedures as a basis for standard operative procedures within their GMP inspectorates. According to Directives 2001/83/EC, 2001/82/EC and 2001/20/EC $(9,22,25)$, an inspector of a Member State competent authority inspects on behalf of the entire EU and these inspections are supposed to be mutually recognised by all Member States. Information obtained during GMP inspections should be kept confidential by inspectors, in accordance with the EU, national, and international laws and agreements. Inspections by a Member State competent authority are carried out on behalf of the entire EU, because GMP non-compliance may have an impact on other Member States. Competent national authorities must take into account information on serious GMP non-compliance received and should follow recommended actions, where the procedures requires to do so, unless their competent authorities can justify alternative courses of action based on specific national considerations, provided that they have no impact on other Member States. With regard to actions, direct or consequential, against marketing authorisations, the Reference Member State ${ }^{1}$ takes initiative for mutual recognition. EMA co-ordinates action regarding centrally authorised products. Each competent national authority takes the responsibility for marketing authorisations on national level alone. The reporting inspectorate should enter information on serious GMP non-compliance in the Eudra GMP telematic system. The procedure requires that the inspectorate discovering serious GMP non-compliance should recommend appropriate action, involving other authorities that share supervisory responsibility in developing such recommendations, and communicate their recommendations to all other authorities in the EU, European Directorate for the Quality of Medicines and Health Care (EDQM), and to countries that have signed a mutual recognition agreement (MRA), Pharmaceutical Inspection Convention / Scheme (PIC/S), $(26,27)$ and New Collaboration Agreement between Drug Regulatory Authorities in Central and Eastern Europe (nCADREAC).

\footnotetext{
${ }^{1}$ EU Member State responsible for drafting the assessment report in the decentralised or mutual recognition procedure for granting marketing authorisation for a medicinal product
} 
European Directorate for the Quality of Medicines and Health Care

European Directorate for the Quality of Medicines and Health Care (EDQM) issues the Certificate of European Pharmacopoeia (CEP), established in 1994. Initially it was limited to active substances, but since 1999 it has included products that pose a risk of transmissible spongiform encephalopathy (TSE). This certification procedure ensures the quality of active substances and excipients and conformance to the European Pharmacopoeia. When applying for a marketing authorisation, the applicant may use CEP as a proof that the used substance conforms to the European Pharmacopoeia. Suspension or voiding of a CEP may be a recommended course of action following an inspection by EDQM of an active substance manufacturer who does not conform to GMP standards anymore. This procedure additionally addresses action to be taken by both manufacturers and regulators in the event of notification by EDQM that a CEP has been voided or suspended (28). There are procedural differences in suspension or cancellation of certificates between EDQM and FDA. If EDQM finds that an active pharmaceutical ingredient API fails to meet GMP requirements, it will set up an ad hoc committee to decide on CEP suspension. If FDA finds non-compliance, it will file a report on which the manufacturer must state its position. If the manufacturer's answers remain unsatisfactory, FDA will send him a warning letter. These two approaches demonstrate differences between the EU and US regulatory systems, where the latter decides based upon the manufacturer's statement, whereas in the EU, manufacturer is not involved in decision-making, but the decision is made by regulators alone.

\section{Pharmaceutical Inspection Convention / Scheme}

Pharmaceutical Inspection Convention (PIC) was established by the European Free Trade Association (EFTA) in 1970. It was an international treaty between

Table 1 Local pharmaceutical manufacturers in Croatia

\begin{tabular}{|c|c|c|}
\hline Manufacturer & Pharmaceutical forms/procedures & Manufacturing site \\
\hline Belupo lijekovi i kozmetika d.d. & $\begin{array}{l}\text { ointments, creams, solutions, tablets, capsules, } \\
\text { powders }\end{array}$ & Koprivnica \\
\hline Cedevita d.o.o. & $\begin{array}{l}\text { primary packaging, quality control, stocking, } \\
\text { delivery }\end{array}$ & Zagreb \\
\hline $\begin{array}{l}\text { Croatian Institute for } \\
\text { Transfusion Medicine }\end{array}$ & $\begin{array}{l}\text { solutions for infusions, concentrates for solutions } \\
\text { for infusion, solutions for injections }\end{array}$ & Zagreb, Hrvatski Leskovac \\
\hline Farmal d.d. & $\begin{array}{l}\text { primary packaging, quality control, stocking, } \\
\text { delivery }\end{array}$ & Ludbreg \\
\hline Fidifarm d.o.o. & $\begin{array}{l}\text { primary packaging, quality control, stocking, } \\
\text { delivery tablets, effervescent tablets, granules, } \\
\text { powders, solutions, gels, shampoos }\end{array}$ & Rakitje \\
\hline Fitofarmacija d.o.o. & $\begin{array}{l}\text { cultivation, drying storage, manufacturing of } \\
\text { herbal medicines }\end{array}$ & Imotski, Rijeka \\
\hline Genera d.d. & $\begin{array}{l}\text { primary packaging, quality control, stocking, } \\
\text { delivery }\end{array}$ & Zagreb \\
\hline $\begin{array}{l}\text { Imunološki zavod d.d./Institute } \\
\text { of Immunology }\end{array}$ & $\begin{array}{l}\text { immunological medicinal products and plasma } \\
\text { derivatives }\end{array}$ & Zagreb, Sveta Nedelja \\
\hline $\begin{array}{l}\text { "Jadran"-Galenski laboratorij } \\
\text { d.d. }\end{array}$ & $\begin{array}{l}\text { sterile solutions, non-sterile solutions, solid } \\
\text { oral forms, primary packaging, quality control, } \\
\text { stocking, delivery }\end{array}$ & Rijeka, Čavle \\
\hline Krka-Farma d.o.o. & $\begin{array}{l}\text { primary packaging, quality control, stocking, } \\
\text { delivery }\end{array}$ & Jastrebarsko \\
\hline Lukaps d.o.o. & hard gelatine capsules & Ludbreg \\
\hline Messer Croatia Plin d.o.o. & medicinal oxygen & Zaprešić \\
\hline PharmaS d.o.o. & $\begin{array}{l}\text { primary packaging, quality control, stocking, } \\
\text { delivery }\end{array}$ & Zagreb \\
\hline Pliva Hrvatska d.o.o. & $\begin{array}{l}\text { active pharmaceutical ingredient, sterile solutions, } \\
\text { solid oral forms }\end{array}$ & Zagreb, Savski Marof \\
\hline Ruđer Medikol Ciklotron d.o.o. & radiopharmaceuticals & Zagreb \\
\hline
\end{tabular}


participating countries, whose main goal was to harmonise GMP rules and the inspection system, and to mutually recognise pharmaceutical reports and inspectors' qualifications between the participants. By 1992, PIC had 18 members, largely from the EU. Since 1992 however, the only body authorised to negotiate international treaties, including mutual recognition between the third countries and Member States has been the European Commission, and PIC became unsustainable. For this reason, PIC has switched from an international treaty to a more flexible form of integration of GMP inspection authorities. The result is the Pharmaceutical Inspection Convention / the Pharmaceutical Inspection Co-operation Scheme (PIC/S). Today PIC/S brings together 37 inspection authorities, mostly from the EU Member States. Applications for PIC/S membership have been submitted by the competent authorities of Saudi Arabia, Bulgaria, China, Croatia, Iran, The Philippines, Serbia, and the USA. It happens every so often that inspection reports filed by a PIC/S member are used by others in planning inspections based on risk management. $\mathrm{PIC} / \mathrm{S}$ is not committed to mutual recognition of inspection reports by its members, but does encourage that (29).

\section{DISCUSSION}

In Croatia several manufacturers make medicinal products for human use in a variety of pharmaceutical forms, including capsules and tablets, semi-solid emulsions, parenteral solutions, lyophilised powders for intravenous and intramuscular administration, syrups, suspensions, and drops (Table 1). These are medicines of all therapeutic groups, plus vaccines, blood components, and medicinal gases. Pharmaceutical industry in Croatia is largely generic, that is, it makes products similar to the ones whose patent protection has expired. With the exception of azithromycin, local manufacturers mainly import active substances and even finished formulations, and it is essential to make sure that GMP is maintained. Local manufacturers receive the manufacturing licence from the Agency for all sites in Croatia where their production takes place. Furthermore, the Agency issues GMP and CPP certificates upon request. These primarily serve for the export of individual batches abroad. Figure 1 shows that the number of issued GMP and CPP certificates dropped in 2009, which can be associated with recent acquisitions in Croatia that resulted in changes to the existing production portfolio of manufacturers. It is possible that the growth of issued GMP/CPP certificates depends on the vitality of the local pharmaceutical industry. Meanwhile, the number of issued production licences was increased, resulting from new generic drug companies that arose as greenfield investments in Croatia. Frequent variations in manufacturing license are an administrative burden, as the license in Croatia is granted for a medicinal product under the trade name, and not for a pharmaceutical form alone, which would be easier to handle, like in the EU countries. Globalisation and mere survival on the market push local manufacturers to export and therefore meet inspection requirements of other EU and non-EU countries (30). For export to the EU countries it is necessary to obtain the EU GMP certificate, and Croatian manufacturers are for that purpose subject to inspection by Member State inspectorates. In Croatia, competence over GMP inspection and regulation is now split between the Ministry and the Agency, whereas in most countries it is a regulatory matter of the Agencies. If GMP inspection were to become the Agency's responsibility, certain administrative and other decisions would be easier to make, because the Agency has complete documentation about medicines and production and experts to evaluate medicinal products. Croatian inspectors participate in some of the meetings of EMA's GMP Inspectors Group and EudraGMP Telematics Groups, although in terms of preparation for EU membership they would benefit much more from field team training with their colleagues from the EU. For Croatia, PIC/S membership would contribute to the promotion of mutual exchange of information and resources.

Considering that most of active substance production has moved to lower-cost geographies, where it is not necessarily supervised by health authorities and where the likelihood of substandard medicines entering the supply chain is greater, it is necessary to inspect the place of active substance production in third countries (31). Therefore, Croatian legislation will need additional provisions to define the inspection of active substance manufacturers by the national authority. According to the current legislation, the Agency may inspect manufacturing sites abroad if that is necessary during the marketing authorisation procedure. However, inspection of active substance manufacturers will require further training of inspectors. This will facilitate exchange of information and mutual recognition of active 
substance inspection reports between Croatia and regulators in the integrated European network.

It is also important that Croatia is included in the Rapid Alert System before joining the EU in order to make the exchange of relevant and urgent information as quick as possible.

Croatia has local production of vaccine and blood components, including integrated active substance production. Vaccine manufacturing standards have been raised high and production requires strict supervision by the Agency. For vaccine manufacturers in developing countries the only possibility of survival on the international market is the WHO Prequalification Programme, which includes a positive assessment of both the manufacturer and the competent authority (32), one that the Croatian Agency has already obtained. Local manufacturers have a qualified person on staff and release batches to the Croatian market, with the exception of the first production batch which may only be released to the market following analyses conducted by the Agency. If the intent is to export the product to the territory of the EU/EEA, the manufacturer must have a qualified person for batch release there. Considering that Croatia is not yet a full member of the European Union, drug batches imported from the EU may not be automatically released on the Croatian market. However, in light of joining the common European market where all barriers to the free movement of goods will be eliminated and in light of the fact that no national agency can conduct a complete batch release analysis for each imported batch, the Agency advocates administrative release of batches imported from the EU in the manner that an analysis is not conducted, but instead the certificate of analysis and the content of the sales presentation are inspected for each imported batch. Pursuant to these, approval is granted for the import of the drug and batch release for the Croatian market. However, drug importers from the third countries are required to undergo Agency analysis for each imported batch (Figure 2).

\section{CONCLUSION}

As local manufacturers increase export, so does Agency's monitoring activity become increasingly internationalised. Besides, both the Agency and the manufacturers are adapting to market conditions that will prevail once Croatia becomes part of the single EU market. To this end, both sides are implementing EU Directives that Croatia has adopted and incorporated into its national legislation. As we move forward, it will become increasingly important to produce well trained inspectors. Every country has its own GMP rules. As regards inspections, what matters most is their regularity, efficacy in enforcing GMP, and quick reporting on non-compliance. Croatia's accession to full membership of the European regulatory network, which promotes exchange of information and resources in the area of GMP and provides education for inspectors, will give a new boost to our fight against pharmaceutical counterfeiting as a global problem and our to strivings to protect patients. Moreover, international co-operation is heading towards a global inspection framework. The new European legislation in the pipeline will place greater direct responsibility on the manufacturer.

\section{REFERENCES}

1. Li B, Suwan J, Martin JG, Zhang F, Zhang Z, Hoppensteadt D, Fareed J, Linhardt RJ. Oversulfated chondroitin sulfate interaction with heparin-binding proteins: New insights into adverse reactions from contaminated heparins. Biochem Pharmacol 2009; 78:293-300.

2. Gerber C, Toelle HG. What happened: the chemistry side of the incident with EMS contamination in Viracept tablets. Toxicol Lett 2009;190:248-53.

3. Wertheimer AI, Norris J. Safeguarding against substandard/ counterfeit drugs: Mitigating a macroeconomic pandemic. Res Social Adm Pharm 2009;5:4-16.

4. Brown CA, Brown SA. Food and Pharmaceuticals: lessons learned from global contaminations with melamine/cyanuric acid and diethylene glycol. Vet Pathol 2010;47:45-52.

5. Tran H, Kleiner BH. Effective executive management in the pharmaceutical industry. J Health Care Finance 2005;32:815

6. Zakon o lijekovima [Act on medicinal products, in Croatian]. Narodne novine 71/2007 [displayed 12 February 2010]. Available at http://narodne-novine.nn.hr/clanci/ sluzbeni/298616.html.

7. Patel KT, Chotai NP. Pharmaceutical GMP: past, present, and future - a review. Pharmazie 2008;63:251-5.

8. Jarvis B. Good manufacturing practice. In: Robinson RK, Batt CA, Patel PD, editors. Encyclopedia of food microbiology. New York: Academic Press Ltd; 2000. p. 961-72.

9. Directive 2001/83/EC of the European Parliament and of the Council on the community code relating to medicinal products for human use [displayed 6 December 2010]. Available at http://ec.europa.eu/health/files/eudralex/vol1/dir_2001_83_cons2009/2001_83_cons2009_en.pdf.

10. Pravilnik o uvjetima i postupku utvrđivanja zahtjeva dobre proizvođačke prakse te o postupku davanja proizvodne dozvole i potvrde o provođenju dobre proizvođačke prakse [Ordinance on conditions and procedures for 
evaluating the GMP requirements and on procedures for granting the manufacturing license and GMP certificate, in Croatian]. Narodne novine 74/2009 [displayed 12 February 2010]. Available at http://narodne-novine.nn.hr/clanci/ sluzbeni/2009_06_74_1774.html.

11. EudraLex. The Rules Governing Medicinal Products in the European Union Volume - 4; Good Manufacturing Practice Part I Basic requirements for Medicinal Products Chapter II Personnel [displayed 12 February 2010]. Available at http:/ec.europa.eu/enterprise/sectors/pharmaceuticals/ files/eudralex/vol-4/pdfs-en/cap2en200408_en.pdf.

12. EudraLex. The Rules Governing Medicinal Products in the European Union Volume - 4; Good Manufacturing Practice Part I Basic requirements for Medicinal Products Chapter III Premise and Equipment [displayed 12 February 2010]. Available at http://ec.europa.eu/ enterprise/sectors/pharmaceuticals/files/eudralex/vol4/pdfs-en/cap3_en.pdf.

13. EudraLex. The Rules Governing Medicinal Products in the European Union Volume - 4; Good Manufacturing Practice Part I Basic requirements for Medicinal Products Chapter IV Documentation [displayed 12 February 2010]. Available at http://ec.europa.eu/enterprise/ sectors/pharmaceuticals/files/eudralex/vol-4/pdfs-en/ cap4en200408.pdf.

14. EudraLex. The Rules Governing Medicinal Products in the European Union Volume - 4; Good Manufacturing Practice Part I Basic requirements for Medicinal Products Chapter V Production [displayed 12 February 2010]. Available at http://ec.europa.eu/enterprise/sectors/ pharmaceuticals/files/eudralex/vol-4/pdfs-en/cap5en. pdf.

15. EudraLex. The Rules Governing Medicinal Products in the European Union Volume - 4; Good Manufacturing Practice Part I Basic requirements for Medicinal Products Chapter VI Quality Control [displayed 12 February 2010]. Available at http://ec.europa.eu/enterprise/sectors/ pharmaceuticals/files/eudralex/vol-4/pdfs-en/2005_10_ chapter_6_en.pdf.

16. EudraLex. The Rules Governing Medicinal Products in the European Union Volume - 4; Good Manufacturing Practice Part I Basic requirements for Medicinal Products Chapter VIII Complaints and Product Recall [displayed 12 February 2010]. Available at http://ec.europa.eu/ enterprise/sectors/pharmaceuticals/files/eudralex/vol4/pdfs-en/2005_12_gmp_part1_chap8_en.pdf.

17. European Medicines Agency (EMA). Compilation of Community Procedures on Inspections and Exchange of Information; Procedure for handling rapid alerts and recalls arising from quality defects [displayed 12 February 2010]. Available at http://www.ema.europa.eu/Inspections/docs/ CoCP/31351006enrev1.pdf

18. EudraLex. The Rules Governing Medicinal Products in the European Union Volume - 4; Good Manufacturing Practice Part I Basic requirements for Medicinal Products Chapter IX Self-Inspection [displayed 12 February 2010]. Available at http://ec.europa.eu/enterprise/ sectors/pharmaceuticals/files/eudralex/vol-4/pdfs-en/ cap9_en.pdf.

19. European Medicines Agency (EMA). Compilation of Community Procedures on Inspections and Exchange of Information; The issue and update of GMP certificates [displayed 12 February 2010]. Available at http://www. ema.europa.eu/Inspections/docs/CoCP/CoCP_GMP certificates_procedure.pdf.

20. European Medicines Agency (EMA). Compilation of Community Procedures on Inspections and Exchange of Information; Guideline on training and qualifications of GMP [displayed 12 February 2010]. Available at Inspectors http://www.ema.europa.eu/Inspections/docs/CoCP/CoCP TrainingQualificationGMPInsp.pdf.

21. Pravilnik o iskaznici farmaceutskog inspektora [Ordinance on pharmaceutical inspector's identity card, in Croatian]. Narodne novine $02 / 2005$ [displayed 12 February 2010]. Available at http://narodne-novine.nn.hr/clanci/sluzbeni/2005_02_19 313.html.

22. Directive 2001/82/EC on the Community code relating to veterinary medicinal products [displayed 8 December 2011] Available at http://www.echamp.eu/fileadmin/user_upload/ Regulation/Directive_2001-82-EC____Consolidated Version_pdf

23. Pravilnik o načinu praćenja neispravnosti u kakvoći lijeka [Ordinance on monitoring of quality defects, in Croatian]. Narodne novine 36/2010.

24. Directive 2003/94/EC laying down principles and guidelines of good manufacturing practice in respect of medicinal products for human use and investigational medicinal products for human use [displayed 7 December 2011] Available at http://ec.europa.eu/health/files/eudralex/vol1/dir_2003_94/dir_2003_94_en.pdf.

25. Directive 2001/20/EC on the approximation of the laws, regulations and administrative provisions of the Member States relating to the implementation of good clinical practice in the conduct of clinical trials on medicinal products for human use [displayed 7 December 2011]. Available at http://www.eortc.be/Services/Doc/clinical-EU-directive-04April-01.pdf.

26. European Medicines Agency (EMA). Compilation of Community Procedures on Inspections and Exchange of Information; Conduct of Inspections of Pharmaceutical Manufacturers [displayed 12 February 2010]. Available at http://www.ema.europa.eu/Inspections/docs/CoCP/ CoCP_InspConduct.pdf.

27. European Medicines Agency (EMA). Compilation of Community Procedures on Inspections and Exchange of Information; Exchange of information on manufacturers and manufacturing or wholesale distribution authorisations between Competent Authorities in the European Economic Area [displayed 12 February 2010]. Available at http:// www.ema.europa.eu/Inspections/docs/CoCP/CoCP_ExInfo. pdf.

28. European Medicines Agency (EMA). Compilation of Community Procedures on Inspections and Exchange of Information; Procedure for dealing with serious GMP noncompliance or voiding/suspension of CEPS thus requiring coordinated administrative action [displayed 12 February 2010]. Available at http://www.ema.europa.eu/Inspections/ docs/CoCP/2356709en.pdf.

29. Morénas J. PICS: un système de coopération en matière d'inspection des produits pharmaceutiques [PICS: Pharmaceutical inspection cooperation scheme, in French]. Ann Pharm Fr 2009;67:16-9.

30. European Medicines Agency (EMA). Compilation of Community Procedures on Inspections and Exchange of 
Information; Outline of a procedure for co-ordinating the verification of the GMP status of manufacturers in third countries [displayed 12 February 2010]. Available at http://www.ema.europa.eu/Inspections/docs/CoCP/CoCP VerificationGMP3rdCountry.pdf.

31. European Medicines Agency (EMA). Compilation of Community Procedures on Inspections and Exchange of Information; Guidance on the occasions when it is appropriate for competent authorities to conduct inspections at the premises of manufacturers of active substances used as starting materials [displayed 12 February 2010].Available at http://www.ema.europa.eu/Inspections/docs/CoCP/CoCP APIGMPInspTriggers.pdf.

32. Milstien J, Costa A, Jadhav S, Dhere R. Reaching international GMP standards for vaccine production: challenges for developing countries. Expert Rev Vaccines 2009;8:559-66. 


\section{Sažetak \\ DOBRA PROIZVOĐAČKA PRAKSA: ULOGA DOMAĆIH PROIZVOĐAČA I NADLEŽNIH TIJELA}

U svakoj zemlji proizvođač lijekova za humanu ili za veterinarsku uporabu obavezan je poslovati sukladno lokalnom zakonodavstvu, koje je u EU usklađeno za sve članice koje moraju poštivati jednake standarde. Zemlje kandidati za članstvo ugrađuju europsko zakonodavstvo u nacionalno i na taj način implementiraju dobru proizvođačku praksu (GMP). Sukladno tomu, proizvođač lijeka obvezan je osigurati da se svi proizvodni postupci za lijekove izvode u skladu s dobrom proizvođačkom praksom i proizvodnom dozvolom uključujući i lijekove koji su namijenjeni samo za izvoz. Ovdje je nezaobilazna i uloga nacionalnih regulatornih tijela posebno Agencije za lijekove i medicinske proizvode koja izdaje proizvodnu dozvolu, GMP certifikate i certifikate o farmaceutskom proizvodu - lijeku (CPP) te provodi laboratorijsku kontrolu proizvoda. GMP inspekciju provodi farmaceutski inspektorat koji je u sastavu Ministarstva zdravstva i socijalne skrbi. Oba su tijela nadležna samo za lijekove za humanu uporabu. Postoje još neka neusklađena pitanja što se tiče prihvaćanja Pravne stečevine na ovome polju, ali kako je Hrvatska zemlja kandidat za punopravno članstvo u EU, očekuje se da će moći demonstrirati da njezina industrija i nadležna tijela poštuju važeće zahtjeve EU i tako potpuno pristupaju europskoj regulatornoj mreži. Stoga je važno jačati institucionalni kapacitet nadležnih tijela, jer nedostatni potencijali mogu izravno utjecati na pacijente ograničavajući im pristup dostupnim terapijama.

KLJUČNE RIJEČI: inspekcija, lijek, odgovorna osoba, osiguranje kakvoće, proizvodnja, provjera kakvoće

\section{CORRESPONDING AUTHOR:}

Siniša Tomić, $\mathrm{PhD}$

Agency for Medicinal Products and Medical Devices

Ksaverska cesta 4

HR-10000 Zagreb, Croatia

E-mail: sinisa.tomic@almp.hr 